\title{
PENDEKATAN SIMULASI MONTE CARLO UNTUK PEMILIHAN ALTERNATIF DENGAN DECISION TREE PADA NILAI OUTCOME YANG PROBABILISTIK
}

\author{
Winda Nur Cahyo \\ Jurusan Teknik Industri, Fakultas Teknologi Industri, \\ Universitas Islam Indonesia, Yogyakarta \\ e-mail: winda@fti.uii.ac.id
}

\begin{abstract}
Tree Diagram has been familiarly known as one of the tools used to solve or to make decision for problems that have some alternatives of solutions. But usually the outcome of the diagram are deterministicly approached. This paper suggested Monte Carlo Simulation to approach the deterministic aspect of outcome to become probabilistic. But there are some asumtions of the diagram must be change to adjust the Monte Carlo Approach.
\end{abstract}

Keywords: Tree Diagram, Monte Carlo Simulation, Decision Analysis.

\section{LATAR BELAKANG}

Diagram Keputusan merupakan alat yang
dapat digunakan untuk membantu
menyelesaikan sebuah kasus yang
mempunyai beberapa alternatif penyelesaian
dengan masing-masing outcome yang muncul
dari pemilihan alternatif yang ada. Dengan
Diagram Keputusan dapat ditentukan expected
value dari masing-masing alternatif
berdasarkan nilai outcome dan probabilitas
masing-masing alternatif.
$\begin{array}{ccc}\text { Namun dalam } & \begin{array}{c}\text { sebuah } \\ \text { Diagram }\end{array} \\ \text { Keputusan, } & \text { nilai } & \text { outcome biasanya }\end{array}$ mempunyai nilai yang tetap (deterministik), sedangkan nilai probabilistiknya ada pada probabilitas masing-masing alternatifnya. Implementasi metode Diagram Keputusan akan menemui kendala ketika dihadapkan pada kasus dimana outcome-nya bersifat probabilistik dan bersifat random. Salah satu alternatif pendekatan yang diusulkan untuk kasus Diagram Keputusan dengan outcome yang random adalah dengan menggunakan pendekatan simulasi Monte Carlo. Misalnya pada contoh kasus yang disampaikan oleh Heizer (2001), outcome dari Decision Tree mempunyai nilai yang deterministik. Nilai outcome yang deterministik pada Decision Tree ini secara aktual relatif susah untuk ditentukan sehingga pendekatan probabilistik dengan model simulasi Monte Carlo pada kasus Heizer (2001) akan dilakukan untuk mempermudah menentukan nilai outcome yang deterministik menjadi nilai yang probabistik. Selain Heizer (2001), contoh implementasi Decision Tree juga ditulis oleh Niwanputri (2007). Sama seperti kasus oleh Heizer (2001). Decision Tree yang digunakan oleh Niwanputri (2007) juga diselesaikan pada kondisi outcome yang deterministik yang pada kondisi tertentu nilai outcome yang deterministik relatif sudah untuk ditentukan. Paper ini akan mengusulkan model Decision Tree yang dikembangkan dengan digabungkan dengan simulasi Monte Carlo.

\section{RUMUSAN MASALAH}

Paper ini akan mengembangkan contoh kasus pada Heizer (2001) dengan mendekati nilai outcome yang deterministik menjadi nilai yang probabilistik. Sehingga perumusan masalah yang disampaikan apakah kombinasi Decision Tree dan Monte Carlo dapat dilakukan untuk menentukan nilai outcome yang tidak dapat ditentukan secara pasti?

\section{TINJAUAN PUSTAKA}

\section{Analisis Keputusan}

Di dunia nyata, sebuah keputusan jarang sekali dibuat dalam lingkungan yang pasti, hampir semua keputusan mengandung resiko (Hick, 1994). Menurut George (1971), secara estimologi, "to decide" (memutuskan) berarti "to cut short" atau "to cut off' yang secara 
sederhana dapat diartikan sebagai "reaching a conclusion". Analisis keputusan adalah sebuah metode yang menyediakan dukungan metode kuantitatif bagi pengambil keputusan di hampir semua area, termasuk di dalamnya bidang rekayasa, analis dalam perencanaan perkantoran dan agen publik, konsultan manajemen proyek, perencana proses manufaktur, analis finasial dan ekonomi, para pakar yang mendukung diagnosa medis dan sebagainya (Heizer, 2001).

Dari pendapat yang disampaikan oleh Heizer (2001), dapat ditarik sebuah kesimpulan bahwa di semua sistem khususnya sistem manajemen, yang ada proses pengambilan keputusan akan membutuhkan proses analisis keputusan. Keputusan akan diambil jika dalam manajemen ada sebuah masalah. Sebuah masalah jika dilihat dari sudut pandang manajemen dapat dikategorikan berdasarkan jangka waktunya, luas lingkungan ruang lingkupnya, dan sifat permasalahan (terstruktur atau tidak). Dalam tiga kategori tersebut maka permasalahpermasalahan dalam manajemen dapat juga dibagi menjadi 3 level yaitu level operasional, taktis, dan strategis.

Menurut Mangkusubroto (1987), analisis keputusan akan sangat bermanfaat dalam menyelesaikan permasalahan yang mempunyai sifat:

a. Unik: permasalahan tidak mempunyai preseden dan di masa depan tidak akan terulang lagi.

b. Tak Pasti: faktor-faktor yang diprediksikan dapat mempengaruhi hasil pengambilan keputusan memiliki kadar pengetahuan dan informasi yang terbatas.

c. Jangka Panjang: hasil pengambilan keputusan mempunyai implikasi dalam jangka yang cukup panjang dan melibatkan sumberdaya-sumberdaya yang penting.

d. Kompleks: preferensi pengambil keputusan atas resiko dan waktu memiliki peranan yang besar.

\section{Diagram Keputusan}

Diagram Keputusan adalah sebuah grafik yang menggambarkan proses pengambilan keputusan yang mengandung alternatif solusi, state of nature dan probabilitasnya serta outcome dari masing-masing alternatif (Heizer, 2001). Secara sederhana Diagram Keputusan dapat digambarkan seperti pada Gambar 1.

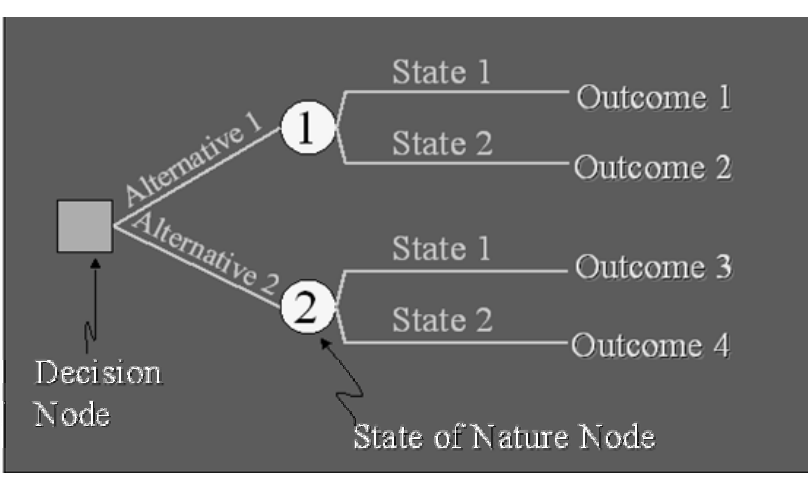

Gambar 1. Gambar Diagram Keputusan

\begin{tabular}{lcrr}
\multicolumn{1}{c}{ Masih menurut Haizer } & $\begin{array}{r}(2001) \text {, } \\
\text { menganalisis }\end{array}$ masalah dengan \\
Keputusan mempunyai & lima \\
penyelesaian, yaitu: & & langkah
\end{tabular}

1. Mendefinisikan Permasalahan

2. Menggambarkan masalah dalam sebuah Diagram Keputusan (seperti pada Gambar 1).

3. Memberikan nilai probabilitas pada masing-masing State of Nature.

4. mengestimasi payoff untuk masing-masing kombinasi alternatif keputusan yang mungkin.

5. Menghitung Expected Monetary Value (EMV) dengan cara mengalikan outcome dengan probabilitasnya.

Persamaan untuk menghitung EMV adalah sebagai berikut:

$$
\operatorname{EMV}(A i)=\sum_{i=1}^{N} V i * P(V i)
$$

dengan:

$\begin{array}{ll}\mathrm{Ai}: & \text { Alternatif } \mathrm{i} \\ \mathrm{N}: & \text { jumlah state of Nature } \\ \mathrm{Vi}: & \text { Nilai Payoff (outcome) } \\ \mathrm{P}(\mathrm{Vi}): & \text { Probabilitas payoff. }\end{array}$

Pada kondisi dimana nilai outcome bersifat deterministik maka nilai EMV untuk masingmasing alternatif akan mudah untuk dihitung, yaitu dengan cara menjumlahkan hasil kali outcome dan probabilitas dari masing-masing 
state-nya. Misalnya pada Gambar 1 pada alternatif 1 , masing-masing state mempunyai nilai probabilitas yang sama yaitu 0,5 dan nilai outcome 1 sebesar Rp. 1 juta dan nilai outcome 2 sebesar Rp. 1.5 juta. Dari nilai-nilai tersebut maka dapat dihitung EMV pada node 1 sebesar Rp. Rp. 1.25 juta $=\left(0,5^{\star} R p .1\right.$ juta)+(0,5*Rp. 1.5 juta). Dengan cara yang sama, dapat juga dihitung EMV pada node 2. Setelah diperoleh EMV pada masing-masing mode maka dapat ditentukan alternatif mana yang dipilih berdasarkan nilai EMV yang diharapkan (bisa maksimum EMV atau minimum EMV) tergantung dari tujuan menjadi fokus penyelesaian kasusnya. Pada EMV, dapat digunakan ukuran apa saja untuk menyatakan nilai ini, tetapi yang umum digunakan adalah ukuran moneter, dalam satuan mata uang seperti Rupiah, Dollar, dan sebagainya (Mangkusubroto, 1987).

\section{Simulasi Monte Carlo}

Simulasi adalah sebuah metode analitik yang bertujuan untuk membuat "imitasi" dari sebuah sistem yang mempunyai sifat acak, dimana jika digunakan model lain menjadi sangat mathematically complex atau terlalu sulit untuk dikembangkan. Simulasi Monte Carlo adalah salah satu metode simulasi sederhana yang dapat dibangun secara cepat dengan hanya menggunakan spreadsheet (misalnya Microsoft Excell). Pembangunan model simulasi Monte Carlo didasarkan pada probabilitas yang diperoleh data historis sebuah kejadian dan frekuensinya, dimana:

$$
\mathrm{Pi}=\mathrm{fi} / \mathrm{n}
$$

dengan:

Pi: Probabilitas kejadian $\mathrm{i}$

fi: frekuensi kejadian $\mathrm{i}$

$\mathrm{n}$ : jumlah frekuensi semua kejadian.

Tetapi dalam simulasi Monte Carlo, probabilitas juga dapat ditentukan dengan mengukur probabilitas sebuah kejadian terhadap suatu distribusi tertentu. Distribusi ini tentu saja telah menjalani serangkaian uji distribusi seperti misalnya uji Chi-square, Heuristic, atau Kolmogorov-Smirnov dan sebagainya.

Outcome dari Diagram Keputusan yang bersifat deterministik kadang kurang bisa mengakomodasi sistem nyata yang mempunyai faktor ketidak pastian yang relatif tinggi. Dengan kekuatan dalam kesederhanaan yang dimiliki oleh metode Monte Carlo ini, maka outcome yang mempunyai faktor ketidakpastian dari sebuah Diagram Keputusan akan dapat diakomodasi keberadaannya. Hal ini dilakukan dengan cara menentukan berbagai nilai outcome beserta probabilitasnya kemudian melakukan simulasi Monte Carlo berdasarkan keluaran bilangan random terhadap probabilitas outcome. Bilangan acak yang digunakan dalam simulasi Monte Carlo ini merupakan sebuah representasi dari situasi yang tidak pasti dalam sebuah sistem nyata (Banks, 1996). Setelah diperoleh nilai outcome hasil simulasi Monte Carlo maka langkah berikutnya adalah melakukan perhitungan dengan cara yang biasa dilakukan dalam Diagram Keputusan.

Penelitian yang dilakukan oleh Siregar (2005), juga menggunakan Simulasi sebagai alat untuk menentukan berbagai macam variabel yang mempengaruhi pengambilan keputusan nilai ekonomis gas alam sebagai pengganti bahan bakar pembangkit tenaga listrik. Dalam penelitian tersebut, simulasi digunakan untuk menentukan nilai berbagai variabel yang berada dalam situasi yang tidak pasti. Tetapi penelitian tersebut secara sederhana juga sebuah proses pengambilan keputusan dengan alternatif keputusan yaitu : Mengganti bahan bakar dengan gas atau tetap dengan bahan bakar yang lama.

\section{KASUS DAN PENGEMBANGAN MODEL}

Untuk lebih memudahkan bagaimana kombinasi 2 metode ini dapat diterapkan, maka diperlukan sebuah kasus untuk membandingkan proses penyelesaiannya. Kasus yang dipilih dalam artikel ini merupakan kasus yang diadopsi dari heizer (2001), yang merupakan kasus Decision Tree untuk menyelesaikan persoalan pemilihan alternatif pada kondisi pasar yang favorable dan unfavorable. Kasus ini jika digambarkan dengan Decision Tree tampak pada Gambar 2, termasuk probabilitas masing-masing state of nature dan nilai outcome-nya yang deterministik. 


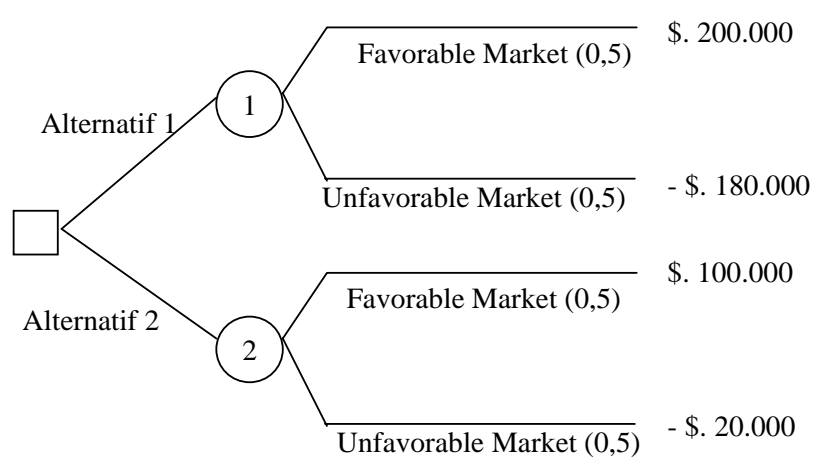

Gambar 2. Contoh Kasus Sederhana dengan Diagram Keputusan (diadopsi dari Hiezer, 2001)

Kasus pada Gambar 2 merupakan contoh sederhana dari sebuah kasus yang diselesaikan dengan Diagram Keputusan. Kasus tersebut adalah kasus pemilihan 2 alternatif yaitu: alternatif 1 (membangun pabrik besar), atau alternatif 2 (membangun pabrik kecil). Nilai probabilitas dari masing-masing state beserta nilai outcome-nya diketahui dan telah tersaji di Gambar 2. Dari kedua alternatif tersebut maka dapat dihitung EMV 1 (dari alternatif 1 ) sebesar $\$ 10.000$ yang diperoleh dari $(0,5 * \$ 200.000)+(0,5 *-\$ 180.000)$ dan EMV 2 diperoleh sebesar \$ 40.000. Karena nilai EMV 2 lebih besar maka alternatif 2 dipilih.

Model Decision Tree pada Gambar 2 akan mudah diselesaikan jika nilai outcome-nya bersifat deterministik. Lain halnya jika outcome-nya tidak bisa diselesaikan secara pasti, maka nilai outcome ini dapat ditentukan dengan memberikan nilai yang berupa range yang masing-masing diberikan nilai probabilitasnya. Sebagai contoh, nilai outcome yang disajikan di Gambar 2 dikembangkan dengan nilai range yang kemudian nilai rerata, nilai atas dan nilai bawahnya masing-masing ditentukan probabilitasnya. Pendekatan probabilistik dari nilai outcome dari Gambar 2 disajikan dalam Tabel 1.

Dari nilai-nilai yang ada di Tabel 1 , dapat dilakukan simulasi Monte Carlo. Misalnya dilakukan 30 kali replikasi untuk masingmasing outcome dengan asumsi probabilitas dari masing-masing state of nature tidak disimulasikan. Hasil simulasi pada 30 kali replikasi disajikan pada Tabel 2. Pada kolom 2,4,6 dan 8 merupakan kolom Bilangan Random untuk keempat state of nature. Pada Kolom 2, state 1 merupakan kondisi favorable pada alternatif 1 , kolom 4: nilai state 2 merupakan kondisi unfavorable pada alternatif 1, pada kolom 6: state 3 merupakan kondisi favorable pada alternatif 1 dan pada kolom 8: state 1 merupakan kondisi unfavorable pada alternatif 1 . Nilai outcome pada kolom 3,5,7 dan 9 diperoleh dari hasil simulasi Monte Carlo berdasarkan pada nilai bilangan random yang muncul di kolom Random Number pada kolom sebelumnya. Misalnya pada replikasi pertama, pada kolom 3, nilai outcome sebesar 250.000 diperoleh dari bilangan random pada kolom 2 yang bernilai 72 . Nilai bilangan random 72 pada kolom ini akan dicocokan dengan nilai range Random Number Assignment di Tabel 1 pada alternatif 1 dan kondisi pasar favorable. Nilai 72 ini masuk pada range ketiga yaitu antara $70-99$, nilai outcome pada range ini adalah sebesar 250.000 sehingga nilai ini yang dipakai sebagai nilai outcome pada state of nature 1 replikasi pertama. Cara ini kemudian dilakukan untuk menentukan nilai outcome pada replikasi yang lain pada state of nature pertama hingga state of nature keempat.

Tabel 1. Pengembangan nilai outcome.

\begin{tabular}{|c|c|c|c|c|}
\hline Alternatif & State & Outcome (\$) & Probabilitas & Random Number Assigment \\
\hline \multirow{6}{*}{ Construct Large Plant } & \multirow{3}{*}{ Favorable Market } & 150.000 & 0.30 & $00-29$ \\
\hline & & 200.000 & 0.40 & $30-69$ \\
\hline & & 250.000 & 0.30 & $70-99$ \\
\hline & \multirow{3}{*}{ Unfavorable Market } & -170.000 & 0.30 & $00-29$ \\
\hline & & -180.000 & 0.40 & $30-69$ \\
\hline & & -190.000 & 0.30 & $70-99$ \\
\hline \multirow{6}{*}{ Construct Small Plant } & \multirow{3}{*}{ Favorable Market } & 125.000 & 0.30 & $00-29$ \\
\hline & & 100.000 & 0.40 & $30-69$ \\
\hline & & 75.000 & 0.30 & $70-99$ \\
\hline & \multirow{3}{*}{ Unfavorable Market } & -18.000 & 0.30 & $00-29$ \\
\hline & & -20.000 & 0.40 & $30-69$ \\
\hline & & -22.000 & 0.30 & $70-99$ \\
\hline
\end{tabular}


Tabel 2. Tabel Simulasi untuk masing-masing State of Nature.

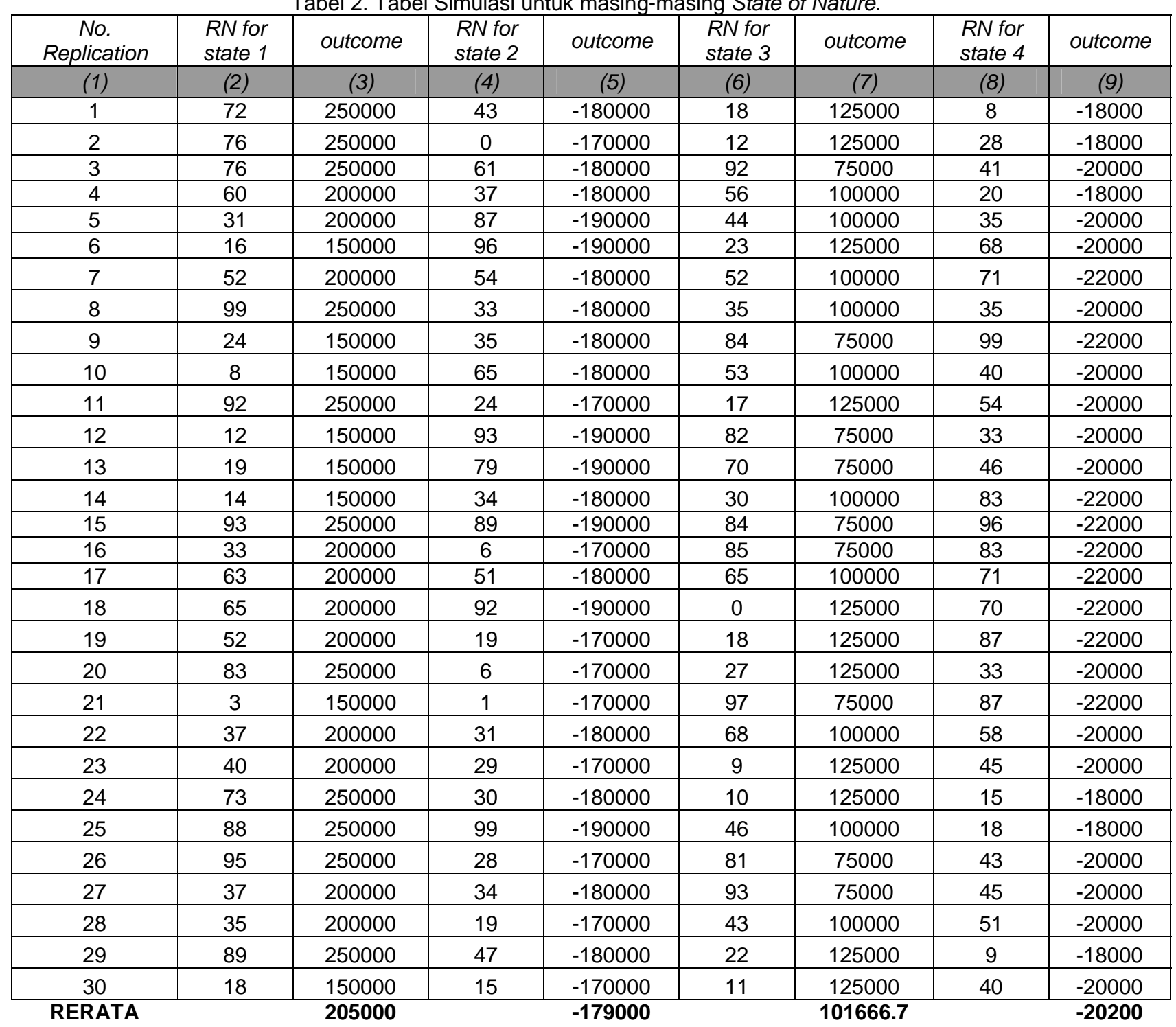

Dari Tabel 2, setelah dilakukan simulasi sebanyak 30 replikasi diperolah nilai outcome untuk keempat State of Nature pada ke-30 replikasi. Ketigapuluh nilai outcome ini lalu dicari reratanya untuk masing-masing state of nature. Nilai rerata ini kemudian dijadikan usulan nilai outcome yang digunakan dalam perhitungan dengan Diagram Keputusan konvensional. Sehingga selanjutnya dapat diperoleh nilai EMV dari masing-masing alternatif adalah sebagai berikut:

a. EMV 1 (untuk alternatif 1 )

$=(0,5 * 205.000)+(0,5 *-179.000)$

$=102.500-89.500$

$=13.000$

b. EMV 2 (untuk alternatif 2)

$=(0,5 * 101.667)+(0,5 *$ * 20.200)

$=50.833,5-10.100$

$=40.733,5$
Dari perhitungan EMV dari masing-masing alternatif diperoleh bahwa EMV 2 mempunyai nilai lebih besar dari EMV 1 sehingga dapat diputuskan bahwa alternatif 2 akan dipilih sebagai keputusan.

\section{PEMBAHASAN}

Pada sub-judul pengembangan model, alternatif yang menjadi pilihan sudah dapat ditentukan dengan mencari nilai EMV yang terbesar dari kedua alternatif tersebut. Setelah dilakukan perhitungan maka diperoleh nilai EMV alternatif 2 mempunyai nilai yang lebih besar dari alternatif yang pertama sehingga alternatif 2 dipilih sebagai keputusan.

Tetapi dalam proses penyelesaian Decision Tree dengan nilai outcome yang tidak dapat ditentukan secara pasti, nilai outcome ini 
akan ditentukan dulu dengan simulasi Monte Carlo. Dengan pendekatan simulasi Monte Carlo, nilai outcome dapat ditentukan dengan mencari Expected Value dari hasil simulasi. Expected Value dalam simulasi bisa berupa nilai rata-rata, nilai modus, median, dan sebagainya. Dalam kasus ini, Expected Value yang diambil adalah nilai rata-rata. Setelah dilakukan simulasi sebanyak 30 kali replikasi untuk semua State of Nature diperoleh nilai Expected Value-nya. Nilai Expected Value ini kemudian digunakan sebagai nilai outcome yang digunakan untuk proses perhitungan EMV. Nilai EMV bisa ditentukan dengan melakukan perhitungan seperti biasa.

Dari proses penyelesaian pada bagian sebelumnya dapat dilihat bahwa Decision Tree dapat dikombinasikan dengan Simulasi Monte Carlo untuk menentukan nilai outcome pada Decision Tree yang tidak dapat ditentukan secara pasti. Jika hal ini terjadi, maka pendekatan nilai outcome yang berupa range dapat dilakukan. Jika diberikan nilai probabilitas di masing-masing range ini, maka Simulasi Monte Carlo dapat dilakukan. Tetapi dalam tahap-tahap penyelesaian kasus ini, ada beberapa hal yang harus mendapatkan perhatian. Hal-hal tersebut adalah sebagai berikut:

a. Diagram Keputusan adalah salah satu metode analisis keputusan, sedangkan salah satu ciri analisis keputusan adalah unik, dalam arti sebuah permasalahan kecil kemungkinan akan terulang di masa yang akan datang, sedangkan dalam metode Monte Carlo, data historis mempunyai peran yang sangat penting dalam pembangunan modelnya. Sehingga ada perbedaan karakteristik permasalahan yang diselesaikan dengan Diagram Keputusan dan Monte Carlo. Untuk menjebatani perbedaan ini diusulkan untuk membangun model Monte Carlo dengan bantuan expert judgement. Expert judgement dibutuhkan pada pembangunan model Monte Carlo untuk menggantikan proses penentuan probabilitas dan kejadian yang dalam Monte Carlo biasanya dilakukan dengan mengolah data historis, hal ini dilakukan karena data historis pada kasus Diagram Keputusan relatif sangat terbatas dan kecil kemungkinan dapat diolah dengan metode pengolahan data yang biasa digunakan dalam Monte Carlo.

b. Cara lain untuk menggantikan expert judgement adalah dengan melihat data historis dari kasus yang mempunyai karakteristik yang relatif sama dan tersedia data historis yang cukup dan memungkinkan untuk diolah dengan pengolahan data Monte Carlo.

c. Dari sisi model (kombinasi Diagram Keputusan dan Monte Carlo), akan semakin tinggi tingkat kompleksitasnya jika Diagram Keputusan mempunyai banyak level dan semua nilai probabilitas pada semua level akan disimulasikan, begitu juga dengan nilai outcome-nya.

\section{KESIMPULAN}

Dari pembahasan dapat diperoleh beberapa kesimpulan yang dapat disampaikan yaitu sebagai berikut:

1. Diagram Keputusan dapat dikombinasikan dengan model simulasi Monte Carlo untuk mendekati nilai outcome yang bersifat deterministik menjadi bersifat probabilistik.

2. Kombinasi kedua metode tersebut juga harus diikuti beberapa penyesuaian, khususnya pada aspek data historis.

3. Komplesitas model kembangan ini dipengaruhi oleh banyak level dari state of nature dan banyaknya outcome.

\section{DAFTAR PUSTAKA}

Banks, J., Carson, J.S., and Nelson, B.L. (1996). Discrete-Event System Simulation $2^{\text {nd }}$ Edition, Prentice-Hall, Inc., New Jersey.

George, Claude S. Jr. (1971). Management for Business and Industry, Prentice-Hall, Inc., New Jersey.

Heizer, J., and Render, B. (2001). Operations Management $6^{\text {th }}$ Edition, Prentice-Hall, Inc., New Jersey.

Hick, Philip E. (1994). Industrial Engineering and Management (A New Perspective), Mc Graw-Hill, Inc., Singapore.

Law, A.M., and Kelton, W.D. (1991). Simulation Modeling and Analysis, Mc Graw-Hill, Inc., Singapore. 
Mangkusubroto, K., dan Trisnadi, L. (1987). Analisis Keputusan: Pendekatan Sistem dalam Manajemen Usaha dan Proyek (Edisi ke-4), Ganeca Exact, Bandung.

Niwanputri, Ginar S. (2007). Penggunaaan Pohon Dalam Decision Tree Analysis Untuk Pengambilan Keputusan Investasi Dalam Perencanaan Bisnis, Prodi Teknik
Informatika Institut Teknologi Bandung. www.informatika.org/ rinaldi/Matdis/20062007/Makalah/Makalah0607-122.pdf Tanggal Akses: 16 Juli 2008.

Siregar, A. B., dan Azwin, R. (2005). Model Evaluasi Nilai Keekonomian Gas Alam Sebagai Bahan Bakar Pembangkit Listrik, Proceding Kongres BKSTI Dan Seminar Nasional Teknik Industri IV, STT MUSI. 